\title{
Control of physical and chemical qualities of milk and dairy food products obtained in an ecologically unfavorable zone
}

\author{
Y.A. Yuldashbaev ${ }^{1}$, R.B. Temiraev ${ }^{2}$, V.V. Tedtova ${ }^{3}$, K.B. Temiraev ${ }^{3}$, \\ R.V. Osikina ${ }^{3}$, M.S. Gazzaeva ${ }^{2}$, L.H. Shugusheva ${ }^{4}$, I.K. Sattsaeva ${ }^{5}$, \\ M.M. Udychak ${ }^{9}$
}

\begin{abstract}
${ }^{1}$ Russian State Agrarian University - Moscow agricultural Academy after K.A. Timiryazev, Moscow 127550, ${ }^{2}$ Gorsky State Agrarian University, Vladikavkaz, 362040, ${ }^{3}$ North-Caucasian Mining and Metallurgical Institute (State Technological University), Vladikavkaz 362021, ${ }^{4}$ Kabardino-Balkarian State University H.M. Berbekov, Nalchik, 360030, ${ }^{5}$ North-Ossetian State University named after K.L. Khetagurov, Vladikavkaz, 362025, ${ }^{6}$ Maykop State Technological University, Maykop 385000, Russian Federation
\end{abstract}

Journal of Livestock Science (ISSN online 2277-6214) 11: 8-13

Received on 1 /11/2019; Accepted on 5/1/2020

doi. 10.33259/JLivestSci.2020.8-13

\begin{abstract}
Heavy metals, which significantly contaminate territory of the Republic of North Ossetia - Alania, Russian Federation, inhibit the effect of many enzymes, their physiological function and metabolism. The research was aimed to study the effectiveness of using preparations enterosorbents Chelaton and Aerosil in lactating cows' diets to enhance ecological and nutritional properties of milk and cheese. Lactating cows in the control group were fed the basic diet (BD). Cows in the $1^{\text {st }}$ test group were fed BD supplemented with the adsorbent Chelaton at a dose of $2 \%$ by weight of the diet dry matter; in the $2^{\text {nd }}$ test group - adsorbent Aerosil at a dose of $40 \mathrm{mg} / \mathrm{kg}$ body weight. All experimental parameters were processed by mathematical analysis using software "Microsoft Excel". The analysis of the diets composition showed that the zinc content exceeded the maximum permissible concentration (MPC) by a factor of 2.5-3.6, lead - 3.0-4.5 and cadmium - 1.9-2.5. Aerosil additives contributed to the increase in cows' milk of the $2^{\text {nd }}$ test group the fat content by $0.22 \%$, protein - by $0.23 \%$, dry matter - by $0.52 \%$, as well as vitamin value of milk, because vitamin C content increased by $33.5 \%$ and vitamin $A-90 \%$. The positive effect of this preparation was on the milk density as well. It should be noted that the fact of reducing in animals' milk of the $2^{\text {nd }}$ test group compared to the control zinc concentration by $58.1 \%$; cadmium - by $5.06 \%$, and lead - by $54.2 \%$. Suitability of milk of all cow groups for cheese making conformed to the $2^{\text {nd }}$ type. Milk of animals in the control group was curded for $27.6 \mathrm{~min}$ and the least time of curdling was in the $2^{\text {nd }}$ test group $-22.5 \mathrm{~min}$. Samples of cheese from the cows' milk of the $2^{\text {nd }}$ test group relative to the control were valued 4.7 points higher.
\end{abstract}

Keywords: lactating cows, heavy metals; enterosorbents; physico-chemical milk composition; processing characteristics; organoleptic evaluation of cheese. 
Yuldashbaev et al. 2020/ J. Livestock Sci. 11: 8-13

\section{Introduction}

The world around us contains a large number of different chemical elements. Certainly the most dangerous of them are heavy metals. They directly affect the human and animal bodies changing their functions and properties. Heavy metals are a group of chemical elements with metal properties and significant atomic weight or density (Tedtova et al., 2004; Kokaeva et al., 2017). Heavy metals include mercury, lead, cadmium, cobalt, copper, zinc, iron. is The quantitative content of trace elements in the diet is not indifferent to the human and animal bodies, since, depending on the concentration the substance may be extremely toxic (Temiraev et al., 2017; Temiraev et al., 2017). The biological and medical significance of heavy metals is determined by their high toxicity and accumulating in the body has negative polytropic effect. This accumulation occurs also at toxic metal levels in natural environments far below the maximum permissible concentration (MPC). They, being metal components, form part of and inhibit the action of many enzymes, hormones and vitamins, thereby, suppressing their physiological function and the metabolism intensity. By food chains they get into the animal body and having accumulated negatively affect the products quality (Temiraev et al., 2017; Kokaeva et al., 2017; Tsalieva et al., 2017; Temiraev et al., 2012).

Enterosorbents, that is, feed preparations, which, due to binding (adsorption) in the gastrointestinal tract, remove these elements from the body are used to detoxify heavy metals in farm animals' nutrition. A good enterosorbent should be safe, not be absorbed from the intestine, have high absorbing capacity and have a selective effect, for example, to bind only metals, without removing vitamins and other beneficial substances (Ibragimova et al., 2006; Temiriev et al., 2009; Kairov et al., 2015). Based on the foregoing, studies on the feeding of Aerosil and Chelaton adsorbents in the diets of lactating cows for the detoxification of heavy metals were carried out for the first time. The present work aimed to study the effectiveness of using preparations enterosorbents Chelaton and Aerosil in lactating cows' diets to enhance ecological and nutritional properties of milk and its derivatives (cheese).

\section{Material and methods}

To achieve this goal scientific and economic experiment on black-pied lactating cows was conducted in the conditions of the collective farm "40 Let Oktyabrya" in Mozdoksky District of the Republic of North Ossetia-Alania (Longitude: $44^{\circ} 40^{\prime} 04^{\prime \prime}$ East, Latitude: $43^{\circ} 02^{\prime} 12^{\prime \prime}$ North. Altitude: $671 \mathrm{~m}$ ). For this purpose, 30 cows after the second lactation were selected and divided by the analogue scale into three groups of 10 animals each. According to the scheme of studies (Table 1), the animals of the control group received the basic diet (BD). Cows of the $1^{\text {st }}$ test group were fed supplemented with adsorbent Chelaton at a dose of $2 \%$ by weight of the diet dry matter; in the $2^{\text {nd }}$ test group - adsorbent Aerosil at a dose of $40 \mathrm{mg} / \mathrm{kg}$ body weight. The daily ration of experimental animals is presented in table 2.

Analysis of feed samples having selected in the territory of the collective farm " 40 Let Oktyabrya" in Mozdoksky District of RNO-Alania showed that the zinc content exceeded the maximum permissible concentration (MPC) by a factor of 2.5-3.6, lead - 3.0-4,5 and cadmium - 1.9-2.5.

The preparations Chelaton and Aerosil were introduced into the standard compound feed composition with the help of a dispenser evenly.

Aerosil preparation manufactured by SILAN LLC (Russia) is anhydrous amorphous silicon dioxide, it belongs to the group of synthetic active highly dispersed mineral adsorbents.

Chelaton - disodium salt of ethylenediaminetetraacetic acid (complexon-III, Trilon B, chelaton III) - an organic compound, the sodium salt of ethylenediaminetetraacetic acid, is a white crystalline powder. one of the most effective chelating agents naturally found in biological organisms for the bonding of metal ions and other toxicants, which ensures high sorption properties of the drug. This drug was purchased from CJSC RUSHIMSET, the first national distributor in Russia.

To determine the milk productivity of the experimental animals, individual control milk yields were carried out once a month. At the same time physico-chemical and technological properties, organoleptic qualities of milk and its derivatives were studied by conventional methods (Kokaeva et al., 2017).

The heavy metal content in samples of feeds and milk was determined by atomic absorption spectrophotometer AAS-3 in the laboratory of agroecology of the Gorsky State Agrarian University, Russian Federation). All provided during the research indices were processed by mathematical analysis using software "Microsoft Excel". 
Table 1 - Scheme of scientific and economic experiment

\begin{tabular}{|l|l|}
\hline Group & \multicolumn{1}{c|}{$\mathrm{n}=10$} \\
\hline Control & Feeding Features \\
\hline 1 test & BD + adsorbent Chelaton at a dose of $2 \%$ by weight of the diet dry matter \\
\hline 2 test & BD + adsorbent Aerosil at a dose of $40 \mathrm{mg} / \mathrm{kg}$ body weight \\
\hline
\end{tabular}

Table 2 - The daily ration of feeding cows

\begin{tabular}{|l|l|l|}
\hline \multicolumn{1}{|c|}{ Indicators } & \multicolumn{1}{c|}{$\begin{array}{c}\text { Normally } \\
\text { required }\end{array}$} & $\begin{array}{l}\text { Actual } \\
\text { Content }\end{array}$ \\
\hline Grass pasture, $\mathrm{kg}$ & - & 25 \\
\hline Green mass of alfalfa, $\mathrm{kg}$ & - & 10 \\
\hline Compound feed typical, kg & - & 3.4 \\
\hline Molasses feed kg & & 0.4 \\
\hline Table salt, g & - & 073 \\
\hline Copper sulfate, $\mathrm{mg}$ & - & 213.7 \\
\hline Cobalt chloride, g & - & 20.36 \\
\hline Manganese sulfate, g & - & 1200 \\
\hline Potassium iodide, mg & - & 10.30 \\
\hline The diet contains: & & \\
\hline exchange energy, MJ $\mathrm{MJ}$ & 126 & 121.3 \\
\hline dry matter, kg & 14.1 & 11.8 \\
\hline crude protein, g & 1630 & 1592 \\
\hline digestible protein, g & 1060 & 1083 \\
\hline crude fiber, g & 3500 & 3345 \\
\hline starch, g & 1435 & 1287 \\
\hline sugar, g & 955 & 858 \\
\hline crude fat, g & 340 & 294 \\
\hline calcium g & 73 & 88.75 \\
\hline phosphorus, g & 51 & 48.9 \\
\hline magnesium g & 22 & 26.24 \\
\hline potassium g & 82 & 194 \\
\hline sulfur, g & 27 & 31.9 \\
\hline iron mg & 850 & 2529 \\
\hline copper mg & 95 & 95 \\
\hline zinc mg & 635 & 915 \\
\hline lead mg & - & 337.3 \\
\hline cadmium mg & - & 25.2 \\
\hline & & \\
\hline
\end{tabular}

\section{Results and Discussion}

In that regard the priority for reducing the heavy metal concentration in animal products is the use of feeds that have sorption, ion-exchange and biologically active properties. For this purpose, enterosorbents Aerosil and Chelaton were widely used in animal husbandry. Aerosil is a silicic acid that has the highest adsorption of all sorbents used in animal husbandry. Chelaton is a complexing compound capable to form stable low dissociative complexes with many divalent and trivalent metals. During 3 months research the effect of the used preparations on milk productivity of the experimental cows was studied (Table 3 ).

According to milk yield of natural fat content significant $(\mathrm{P}<0.95)$ differences between the cows of the control group $(1089.3 \mathrm{~kg})$ and the animals of the $1^{\text {st }}$ test $(1099.5 \mathrm{~kg})$ and $2^{\text {nd }}$ test $(1122.6 \mathrm{~kg})$ groups were not established. Hence, detoxification of heavy metals does not affect the milk yield of natural fat content. 
Table 3 - Milk productivity of cows

\begin{tabular}{|l|l|l|l|}
\hline \multicolumn{1}{|c|}{ Index } & \multicolumn{3}{c|}{$\mathrm{n}=10$} \\
\cline { 2 - 4 } & $\begin{array}{l}\text { Contr } \\
\text { ol }\end{array}$ & 1 test & 2 test \\
\hline $\begin{array}{l}\text { Yield of natural fat } \\
\text { content, kg }\end{array}$ & $1089.3 \pm 24.4$ & $1099.5 \pm 24.8$ & $1122.6 \pm 21.9$ \\
\hline $\begin{array}{l}\text { Milk content, \%: } \\
\text { fat }\end{array}$ & $3.46 \pm 0.03$ & $3.63 \pm 0.04^{*}$ & $3.68 \pm 0.07^{*}$ \\
\hline protein & $3.20 \pm 0.03$ & $3.38 \pm 0.03^{*}$ & $3.43 \pm 0.04^{*}$ \\
\hline $\begin{array}{l}\text { Absolute yield: } \\
\text { milk fat, kg }\end{array}$ & $37.7 \pm 0.36$ & $39.9 \pm 0.34^{*}$ & $41.3 \pm 0.36^{*}$ \\
\hline Milk protein & $34.8 \pm 0.29$ & $37.2 \pm 0.33^{*}$ & $38.5 \pm 0.34^{*}$ \\
\hline $\begin{array}{l}\text { Yield of basic fat } \\
\text { content, kg }\end{array}$ & $1046.3 \pm 24.1$ & $1108.7 \pm 21.0^{*}$ & $1147.5 \pm 26.0^{*}$ \\
\hline In \% for control & 100.0 & 106.0 & 109.7 \\
\hline
\end{tabular}

$* \mathrm{P}>0,95$

Application of absorbent Aerosil as a detoxicant activated the processes of rumen metabolism, which, first of all, contributed to the intensification of fat and protein synthesis in the cows' mammary gland. Due to this, the highest yield of milk fat and protein had animals of the $2^{\text {nd }}$ test group, having significantly $(P>0.95)$ exceeded in these indices the control by $3.6 \mathrm{~kg}$ or $9.5 \%$ and $3.7 \mathrm{~kg}$ or $10.6 \%$.

Based on milk yield of natural fatness and fat content in milk, the milk yield of $3.6 \%$ (basic) fat content was calculated. By milk yield of the basic fat content the dairy industry enterprises are paid off the manufactures of the region. Aerosil supplements during the experiment provided for cows of the $2^{\text {nd }}$ experimental group $(1147.5 \mathrm{~kg})$ the highest yield of the basic fat content having significantly $(\mathrm{P}<0.95)$ exceeded their control counterparts in this index by $1012 \mathrm{~kg}$ or $9.7 \%$.

The results presented in Table 4 show that the use of preparations Chelaton and Aerosil in cows' diets of the $1^{\text {st }}$ and $2^{\text {nd }}$ test groups of the experiment contributed to increasing the physico-chemical properties of milk.

Table 4 - Physico-chemical composition of cows' milk

\begin{tabular}{|l|l|l|l|}
\multicolumn{1}{|c|}{ Index } & \multicolumn{3}{c|}{$\mathrm{n}=10$} \\
\cline { 2 - 4 } & Control & I test & II test \\
\hline Dry matter, \% & $12.27 \pm 1.10$ & $12.54 \pm 0.05^{*}$ & $12.79 \pm 0.11^{*}$ \\
\hline Fat, \% & $3.46 \pm 0.05$ & $3.63 \pm 0.04^{*}$ & $3.68 \pm 0.07^{*}$ \\
\hline Protein, \% & $3.20 \pm 0.02$ & $3.38 \pm 0.03^{*}$ & $3.43 \pm 0.04^{*}$ \\
\hline Lactose, \% & $4.51 \pm 0.06$ & $4.38 \pm 0.08$ & $4.57 \pm 0.06$ \\
\hline Vitamin C, mg/l & $14.9 \pm 0.68$ & $15.9 \pm 0.55$ & $19.9 \pm 0.21^{*}$ \\
\hline Vitamin A, mg/l & $0.20 \pm 0.02$ & $0.31 \pm 0.03^{*}$ & $0.38 \pm 0.03^{*}$ \\
\hline Density, ${ }^{\circ} \mathrm{A}$ & $28.15 \pm 0.12$ & $28.57 \pm 0.13^{*}$ & $28.79 \pm 0.14^{*}$ \\
\hline Acidity, ${ }^{\circ} \mathrm{T}$ & $18.11 \pm 0.34$ & $17.85 \pm 0.31$ & $17.89 \pm 0.29$ \\
\hline Zinc, $\mathrm{mg} / \mathrm{l}$ & $3.46 \pm 0.19$ & $3.49 \pm 0.19^{*}$ & $1.45 \pm 0.11^{*}$ \\
\hline Ash, \% & $1.16 \pm 0.02$ & $1.15 \pm 0.04$ & $1.11 \pm 0.03$ \\
\hline Cadmium, $\mu \mathrm{g} / \mathrm{l}$ & $18.2 \pm 0.15$ & $15.6 \pm 0.24^{*}$ & $9.0 \pm 0.16^{*}$ \\
\hline Lead, $\mathrm{mg} / \mathrm{l}$ & $0.24 \pm 0.007$ & $0.16 \pm 0.006^{*}$ & $0.11 \pm 0.004^{*}$ \\
\hline
\end{tabular}

$* \mathrm{P}>0.95$

Enterosorbent Aerosil supplements contributed to a significant increase $(\mathrm{P}>0.95)$ in the cows' milk of the $2^{\text {nd }}$ test group versus the control the content of fat by $0.22 \%$, protein by $0.23 \%$, dry matter by $0.52 \%$ and milk vitamin value since the content of vitamin $\mathrm{C}$ increased by $33.5 \%$ and vitamin $\mathrm{A}-$ by $90 \%$. The positive effect of this preparation was also on the density of milk. The cows of the $2^{\text {nd }}$ test group exceeded the control counterparts in this index by $0.64^{\circ} \mathrm{A}$, resulting from the increase of milk dry matter. 
On the positive side, it should be noted the fact of decreasing zinc concentration by $58.1 \%$ (P<0.05); cadmium - by 5.06\% ( $\mathrm{P}<0.05)$ and lead $-54.2 \%(\mathrm{P}<0.05)$ in milk of animals from the $2^{\text {nd }}$ test group compared to the control. This indicates that Aerosil has high adsorption properties.

To study technological properties of milk is important for its qualitative characteristics in test groups consuming diets with the excessive amount of heavy metals. Therefore, at the end of the lactation, samples of Ossetian (fresh) pickled cheese were produced from cows' milk of all groups at the Mozdok Dairy Plant (RNOAlania). The suitability of all experimental cows' milk for cheese-making was estimated by the time of its rennet (chymosin) curdling while recording the acidity and milk temperature (Table 5).

Table 5 - Suitability of experimental cows' milk by the time of rennet curdling

\begin{tabular}{|l|l|l|l|l|l|}
\hline Cows' group & $\begin{array}{l}\% \text { of milk } \\
\text { protein }\end{array}$ & $\begin{array}{l}\text { Milk } \\
\mathrm{pH}\end{array}$ & $\begin{array}{l}\text { Temperature } \\
{ }^{\circ} \mathrm{C}\end{array}$ & $\begin{array}{l}\text { Length of } \\
\text { curdling, min. }\end{array}$ & Milk type \\
\hline Control & 3.46 & 6.45 & 35 & 27.6 & 2 \\
\hline 1 test & 3.63 & 6.35 & 35 & 25.0 & 2 \\
\hline 2 test & 3.68 & 6.20 & 35 & 22.5 & 2 \\
\hline
\end{tabular}

* Note: according to milk suitability for cheese-making, milk is divided into three types: 1 - milk, curdled under the rennet effect for nearly 15 minutes; 2 - from 16 to 40 minutes and 3 - curdling for more than 40 minutes.

According to milk suitability of all cow groups for cheese-making conformed to the $2^{\text {nd }}$ type. But by the length of milk curdling there was a difference between the groups. Milk of animals in the control group was curded for $27.6 \mathrm{~min}$, in the $1^{\text {st }}$ test group - for $27.5 \mathrm{~min}$ and the least time of curdling was in the $2^{\text {nd }}$ test group $-22.5 \mathrm{~min}$. Rennet clot in all groups was dense and elastic with normal syneresis (wheying). Samples of cheese after 10-day aging in the pickle had a good marketable state.

The organoleptic properties of the Ossetian cheese samples were rated on a 100-point scale by the tasting commission. The tasting results with the conditional 5, 10 rating of the test, appearance, packaging and marking, respectively are given in Table 6 .

Table 6 - Tasting evaluation of Ossetian (fresh) pickled cheese

\begin{tabular}{|l|l|l|l|l|}
\hline \multirow{2}{*}{ Organoleptic characteristics } & \multirow{2}{*}{ Points } & \multicolumn{3}{|c|}{ Cheese samples from cows' milk } \\
\cline { 3 - 5 } & & Control group & 1 test group & 2 test group \\
\hline Taste and smell & 45 & 39.3 & 40.8 & 42.2 \\
\hline Consistency & 25 & 21.2 & 21.2 & 22.0 \\
\hline Pattern & 10 & 8.3 & 8.9 & 9.3 \\
\hline Total & 100 & 88.8 & 91.5 & 93.5 \\
\hline Grade & & top & top & top \\
\hline
\end{tabular}

According to taste and smell (over 37 points) and the total number of points (over 88 points) cheese samples from milk of all groups were rated as a top grade. The least score the tasting commission gave to the cheese sample from the cows' milk of the control group - 88.8. Cheese samples from the cows' milk of $1^{\text {st }}$ and $2^{\text {nd }}$ test groups in relation to the control were rated, respectively, 2.7 and 4.7 points more.

Analysis of feed samples having selected in the territory of the collective farm " 40 Let Oktyabrya" in Mozdoksky District of RNO-Alania showed that the zinc content exceeded the maximum permissible concentration (MPC) by a factor of 2.5-3.6, lead - 3.0-4,5 and cadmium - 1.9-2.5. Application of absorbent Aerosil as a detoxicant activated the processes of rumen metabolism, which, first of all, contributed to the intensification of fat and protein synthesis in the cows' mammary gland.

Enterosorbent Aerosil supplements contributed to a significant increase ( $\mathrm{P}>0.95)$ in the cows' milk of the $2^{\text {nd }}$ test group versus the control the content of fat by $0.22 \%$, protein by $0.23 \%$, dry matter by $0.52 \%$ and milk vitamin value since the content of vitamin C increased by $33.5 \%$ and vitamin $\mathrm{A}-$ by $90 \%$.

According to milk suitability of all cow groups for cheese-making conformed to the $2^{\text {nd }}$ type. But by the length of milk curdling there was a difference between the groups. Milk of animals in the control group was curded for $27.6 \mathrm{~min}$, in the $1^{\mathrm{st}}$ test group - for $27.5 \mathrm{~min}$ and the least time of curdling was in the $2^{\text {nd }}$ test group $-22.5 \mathrm{~min}$. 
Cheese samples from the cows' milk of $1^{\text {st }}$ and $2^{\text {nd }}$ test groups in relation to the control were rated, respectively, 2.7 and 4.7 points more.

Conclusion To increase the physico-chemical and technological properties of cows' milk produced in conditions of high heavy metal content in feeds, adsorbent Aerosol at a dose of $40 \mathrm{mg} / \mathrm{kg}$ body weight should be added to their diets.

\section{References}

1) Ibragimova Z.R., Tedtova V.V., Temiraev R.B., Tsalieva L.V., Ibragimova O.T. 2006. Biological resources of young pigs in conditions of technogenic tension / Z.R. Ibragimova, Materials of the IV International Scientific Conference "Topical problems of biology in animal husbandry". Borovsk, pp. 267-270.

2) Kairov V.R., Chokhataridi L.G., Bokieva S.B., Dzodzieva E.S., Shiolashvili D.G. 2015. Influence of adsorbents on the processes of digestive and intermediary metabolism of fattened bulls during heavy metals detoxification. Proceedings of Gorsky State Agrarian University, Vladikavkaz 52(1): 61-65.

3) Kokaeva M.G., Gogaev O.K., Cugkiev B.G., Kokaeva F.F., Galicheva M.S. 2017. Method of the metabolism optimization in cows and effects on the consumer properties of milk during denitrification. Asian Journal of Microbiology, Biotechnology and Environmental Sciences 19(3): 741-748.

4) Kokaeva, M.G., Temiraev, R.B., Beslaneev, E.V., Cherchesova, S.K., Kubatieva (Gutieva), Z.A. and Kozyrev, S.G. 2017. Influence of antioxidant and adsorbent on the processes of digestive and intermediate metabolism in lacting cows during denitrification. Journal of Pharmaceutical Sciences and Research. 9 (12): 2401-2404.

5) Tedtova V.V., Gubieva M.A., Khamitsaeva E.S. 2004. Ways to reduce feed toxicity. / V.V. Tedtova, // Materials of the V international conference "Stable Development of Mountain Territories: Problems and Prospects for Integrating Science and Education". Vladikavkaz pp. 507-508.

6) Temiraev R.B. Vityuk L.A., Kokaeva M.G., Djibilova N.S., Kanukov A.M. 2012. A way to improve the consumer qualities of Ossetian cheese. Proceedings of Gorsky State Agrarian University, Vladikavkaz 49(3): $169-173$.

7) Temiraev R.B., Kozyrev S.G., Kononenko S.I., Baeva A.A., Bobyleva L.A. and Kalabekov A.L. 2017. Impact of the breed-specific characteristics on the metabolism and heavy metal accumulation in the organs and tissues of calves. Journal of Pharmaceutical Sciences and Research 9 (6): 780-784.

8) Temiriev V.Kh., Baeva Z.T., Ter-Teriyan N.G., Techiev S.R. 2009. Antioxidants in cows' diets, Mixed feed 5: 71.

9) Temiraev V.Kh., Kairov V.R., Temiraev R.B., Kubatieva Z.A. and Gukezhev V.M. 2017. Method to improve productive performance and digestive metabolism of broilers with reduced risk of aflatoxicosis. Ecology, Environment and Conservation 23 (1): 554-561.

10) Tsalieva L.V., Temiraev R.B., Kononenko S.I., Dzagurov B.A., Gazzaeva M.S., Grevtsova S.A. 2017. Ecological and consumer properties of pig meat from different breeds produced in technogenic zone. Journal of Pharmaceutical Sciences and Research 9 (12): 2397-2400.

11) Yarmots A.V., Temiraev R.B., Vityuk L.A., Kokaeva M.G., Plieva Z.K. 2013. A way to improve the ecological and nutritional qualities of milk and dairy products, New technologies, Maykop 3, pp 128-134. 